\section{Clean Chip Residual: A Substrate Component for Growing Annuals}

\author{
Cheryl R. Boyer ${ }^{1,2,7}$, Glenn B. Fain ${ }^{1,3}$, Charles H. Gilliam ${ }^{1,4}$, \\ Thomas V. Gallagher ${ }^{5}$, H. Allen Torbert ${ }^{6}$, and Jeff L. Sibley ${ }^{1,4}$
}

ADDITIONAL INDEX wORDS. peat moss, pine bark, alternative media, ageratum, salvia, impatiens, forest by-products, forestry, wood fiber

\begin{abstract}
Summary. A study was conducted at Auburn University in Auburn, AL, and the U.S. Department of Agriculture-Agricultural Research Service, Southern Horticultural Laboratory in Poplarville, MS, to evaluate clean chip residual (CCR) as an alternative substrate component for annual bedding plant production. Clean chip residual used in this study was processed through a horizontal grinder with 4 -inch screens at the site and was then processed again through a swinging hammer mill to pass a 3/4- or $1 / 2$-inch screen. Two CCR particle sizes were used alone or blended with $10 \%(9: 1)$ or $20 \%(4: 1)$ peatmoss (PM) (by volume) and were compared with control treatments, pine bark $(\mathrm{PB})$, and $\mathrm{PB}$ blends $(10 \%$ and 20\% PM). Three annual species, 'Blue Hawaii' ageratum (Ageratum houstonianum), 'Vista Purple' salvia (Salvia $\times$ superba), and 'Coral' or 'White' impatiens (Impatiens walleviana), were transplanted from 36-cell (12.0-inch $\left.{ }^{3}\right)$ flats into 1 -gal containers, placed on elevated benches in a greenhouse, and hand watered as needed. Ageratum plants grown at Auburn had leaf chlorophyll content similar or greater than that of plants grown in PB. There were no differences in salvia; however, impatiens plants grown in PB substrates at Auburn had less leaf chlorophyll content than those grown in CCR. There were no differences in ageratum, salvia, or impatiens leaf chlorophyll content at Poplarville. There were no differences in growth indices (GI) or shoot dry weight (SDW) of ageratum, while the largest salvia was in PB:PM and the largest impatiens were in PB-based substrates at Auburn. The GI of ageratum at Poplarville was similar among treatments, but plants grown in 4:1 1/2-inch CCR:PM were the largest. Salvia was largest in 4:1 CCR:PM and PB:PM, and although there were no differences in GI for impatiens at Poplarville, the greatest SDW occurred with PB:PM. Foliar nutrient content analysis indicated elevated levels of manganese and zinc in treatments containing CCR at Auburn and PB at Poplarville. At the study termination, two of three annual species tested at both locations had very similar growth when compared with standard PB substrates. This study demonstrates that CCR is a viable alternative substrate in greenhouse production of ageratum, salvia, and impatiens in large containers.
\end{abstract}

$\mathrm{I}$ $\mathrm{n}$ the southeastern United States, many greenhouse growers have moved toward producing l-gal

Plants for this project were donated by Young's Plant Farm, Auburn, AL.

Mention of trade names or commercial products in this article is solely for the purpose of providing specific information and does not imply recommendation or endorsement by the U.S. Department of Agriculture.

${ }^{1}$ Auburn University, Department of Horticulture, Auburn, AL 36849

${ }^{2}$ Graduate Research Assistant.

${ }^{3}$ Former Research Horticulturist, USDA-ARS, Southern Horticultural Laboratory, Poplarville, MS 39470. Currently, Assistant Professor of Horticulture, Auburn University.

${ }^{4}$ Professor of Horticulture.

${ }^{5}$ Assistant Professor, Auburn University, School of Forestry and Wildlife Sciences.

${ }^{6}$ Soil Scientist and Research Leader, USDA-ARS, National Soil Dynamics Laboratory, Auburn, AL 36832 .

${ }^{7}$ Corresponding author. E-mail BOYERCR@auburn. edu. or larger containers for the landscape market due to an interest in large finished containers for consumer "instant landscapes." The substrates used in these large containers are composed primarily of aged pine bark blends. These materials provide support for plant growth structurally as and Canadian sphagnum peatmoss well as providing a nutrient and water reservoir. Pine bark $(\mathrm{PB})$ and peatmoss (PM) are ideal substrates because they are largely inert, pathogenfree, and have been readily available. However, a study by Lu et al. (2006) showed a consistent decline in the availability (and subsequent rise in price) of $\mathrm{PB}$ due to reduced domestic forestry production, increased importation of logs (no bark), increased in-field harvesting (leaving bark on the forest floor rather than at the mill), and the use of $\mathrm{PB}$ as a source of fuel. The large containers require significantly more substrate than has previously been needed for crop production, resulting in profit loss for many growers.

Clean chip residual (CCR) is a potential substrate substitute for PB. CCR is derived from the forestry production process of thinning pine plantations using mobile equipment to harvest and process small trees directly in the field. This process, first carried out when the plantation is about 10 to 15 years old, results in two products: clean chips (used for making paper products) and CCR (everything else, including wood, needles, and bark). The resulting CCR product is composed of $\approx 50 \%$ wood, $40 \%$ bark, and $10 \%$ needles (data not shown) and is sold for boiler fuel, or more commonly, is left in the field and spread across the harvested area. The use of CCR has the potential to provide a sustainable media resource that is able to meet the continuing needs of the greenhouse industry and have a value-added benefit to forestry landowners.

The objective of this work was to evaluate freshly processed CCR (two screen sizes) as a substrate component or a PB replacement for production of greenhouse-grown annual crops in large containers.

\begin{tabular}{llll}
\hline $\begin{array}{l}\text { Units } \\
\text { To convert U.S. to SI, } \\
\text { multiply by }\end{array}$ & U.S unit & SI unit & $\begin{array}{l}\text { To convert SI to U.S., } \\
\text { multiply by }\end{array}$ \\
\hline 0.3048 & $\mathrm{ft}$ & $\mathrm{m}$ & 3.2808 \\
3.7854 & gal & $\mathrm{L}$ & 0.2642 \\
2.54 & inch(es) & $\mathrm{cm}$ & 0.3937 \\
25.4 & inch(es) & $\mathrm{mm}$ & 0.0394 \\
16.3871 & inch & $\mathrm{cm}^{3}$ & 0.0610 \\
0.0160 & lb $/ \mathrm{ft}^{3}$ & $\mathrm{~g} \cdot \mathrm{cm}^{-3}$ & 62.4274 \\
0.5933 & lb $/ \mathrm{yard}^{3}$ & $\mathrm{~kg} \cdot \mathrm{m}^{-3}$ & 1.6856 \\
1.6093 & mile $(\mathrm{s})$ & $\mathrm{km}$ & 0.6214 \\
1 & $\mathrm{mmho} / \mathrm{cm}$ & $\mathrm{mS} \cdot \mathrm{cm}^{-1}$ & 1 \\
1 & $\mathrm{ppm}$ & $\mathrm{mg} \cdot \mathrm{kg}^{-1}$ & 1 \\
$\left({ }^{\circ} \mathrm{F}-32\right) \div 1.8$ & ${ }^{\circ} \mathrm{F}$ & ${ }^{\circ} \mathrm{C}$ & $\left(1.8 \times{ }^{\circ} \mathrm{C}\right)+32$
\end{tabular}

Hartectunology · July-September 2008 18(3) 


\section{Materials and methods}

The CCR used in this study was obtained from a 10 - to 12 -year-old loblolly pine (Pinus taeda) plantation near Evergreen, AL, which was thinned and processed for clean chips using a total tree harvester (Peterson DDC-5000-G Portable Chip Plant; Peterson Pacific Corp., Eugene, OR), a horizontal grinder with 4 -inch screens (Peterson 4700B Heavy Duty Horizontal Grinder; Peterson Pacific Corp.), and a swinging hammer mill (No. 30; C.S. Bell, Tifton, OH) with a $3 / 4$ - or $1 / 2$-inch screen. These two CCR particle sizes were used 4:1 (20\%) PM (by volume) and were compared with $\mathrm{PB}$ and $\mathrm{PB}$ blends (9:1 and 4:1 PM by volume; Table 1). The PB used in this study was obtained from Pineywoods Mulch Co. (Alexander City, AL). The PB used at Poplarville was transported from Auburn to ensure its source and consistency. Substrates were mixed at Poplarville before splitting material between Poplarville and Auburn for the study. Auburn substrates were then transported to Paterson Greenhouse Complex for study installation in Auburn.

This study was conducted at two locations: U.S. Department of Agriculture, Agricultural Research Service, Southern Horticultural Laboratory, Poplarville, MS (23 Feb. 2006), and at Paterson Greenhouse, Auburn University, Auburn, AL (12 Apr. 2006). These locations were alone or blended with 9:1 (10\%) or

chosen due to their location in the southeastern United States where the practice of growing annuals in large containers is becoming common. Auburn and Poplarville are located $\approx 350$ miles apart. Poplarville is $\approx 60$ miles from the Gulf of Mexico, while Auburn is more than 200 miles from the Gulf of Mexico. Plants at Poplarville were placed in a single-layer corrugated polycarbonate greenhouse covered with a $30 \%$ shadecloth from 1000 to $1400 \mathrm{HR}$ daily, while plants at Auburn were placed in a twin wall polycarbonate greenhouse with no additional shade for the duration of the study. Greenhouse facilities in Poplarville had a 12 -ft gutter height and a crushed limestone floor, while the Auburn greenhouse had a 16-ft gutter height with a concrete floor. Greenhouses were maintained at a $22^{\circ} \mathrm{C}$ day and $17^{\circ} \mathrm{C}$ night temperature in Poplarville and $29^{\circ} \mathrm{C}$ day and $18^{\circ} \mathrm{C}$ night in Auburn.

Each substrate blend was preplant incorporated with $12 \mathrm{lb} /$ yard $^{3}$ $15 \mathrm{~N}-3.9 \mathrm{P}-9.9 \mathrm{~K}$ controlled-release fertilizer (Osmocote 15-9-12, 3-4 month release; Scotts Co., Marysville, $\mathrm{OH}), 5 \mathrm{lb} / \mathrm{yard}^{3}$ dolomitic limestone, and $1.5 \mathrm{lb} /$ yard $^{3}$ Micromax (Scotts Co.). Three annual species, ageratum, salvia, and impatiens, were transplanted from 36-cell (12.0inch $^{3}$ ) flats into 1 -gal containers. Plants at both locations were arranged by species in a randomized complete block with seven singleplant replications on elevated benches

Table 1. Physical properties of pine bark-based and clean chip residual-based substrates. $^{\mathrm{z}}$

\begin{tabular}{|c|c|c|c|c|}
\hline \multirow[b]{2}{*}{ Substrate $^{\mathrm{y}}$} & $\begin{array}{c}\text { Air } \\
\text { space }^{\mathrm{x}}\end{array}$ & $\begin{array}{l}\text { Container } \\
\text { capacity }^{\mathrm{w}}\end{array}$ & $\begin{array}{c}\text { Total } \\
\text { porosity }^{v}\end{array}$ & \multirow{2}{*}{$\begin{array}{c}\text { Bulk density } \\
\left(\mathrm{g} \cdot \mathrm{cm}^{-3}\right)^{\mathrm{u}} \\
\end{array}$} \\
\hline & \multicolumn{3}{|c|}{ (\% vol) } & \\
\hline $100 \% \mathrm{~PB}$ & $36 \mathrm{~d}^{\mathrm{t}}$ & $49 \mathrm{c}$ & 85 bc & $0.17 \mathrm{c}$ \\
\hline $100 \% 3 / 4$-inch CCR & $47 \mathrm{a}$ & $38 \mathrm{f}$ & $85 \mathrm{bc}$ & $0.18 \mathrm{~b}$ \\
\hline $100 \% 1 / 2$-inch CCR & $44 \mathrm{~b}$ & $42 \mathrm{e}$ & $86 \mathrm{ab}$ & $0.18 \mathrm{~b}$ \\
\hline 9:1 PB:PM & $34 \mathrm{de}$ & $5 \mathrm{lb}$ & $85 \mathrm{bc}$ & $0.17 \mathrm{c}$ \\
\hline 9:1 3/4-inch CCR:PM & $39 \mathrm{c}$ & $45 \mathrm{~d}$ & $84 c$ & $0.19 \mathrm{a}$ \\
\hline 9:1 1/2-inch CCR:PM & $39 \mathrm{c}$ & $46 \mathrm{~d}$ & $85 \mathrm{ab}$ & $0.18 \mathrm{ab}$ \\
\hline 4:1 PB:PM & $31 \mathrm{e}$ & $56 \mathrm{a}$ & $87 \mathrm{a}$ & $0.16 \mathrm{~d}$ \\
\hline 4:1 3/4-inch CCR:PM & $33 \mathrm{de}$ & $53 \mathrm{~b}$ & $86 \mathrm{ab}$ & $0.18 \mathrm{~b}$ \\
\hline 4:1 1/2-inch CCR:PM & $31 \mathrm{e}$ & $55 \mathrm{a}$ & $86 \mathrm{ab}$ & $0.18 \mathrm{~b}$ \\
\hline
\end{tabular}

${ }^{2}$ Analysis performed using the North Carolina State University porometer.

y $\mathrm{PB}=$ pine bark, $C C R=$ clean chip residual, $\mathrm{PM}=$ sphagnum peatmoss $(1$ inch $=2.54 \mathrm{~cm})$

"Air space is volume of water drained from the sample $\div$ volume of the sample.

wContainer capacity is (wet weight - oven dry weight) $\div$ volume of the sample.

Total porosity is container capacity + air space.

uBulk density after forced-air drying at $105^{\circ} \mathrm{C}\left(221.0^{\circ} \mathrm{F}\right)$ for $48 \mathrm{~h}\left(\mathrm{l} \mathrm{g} \cdot \mathrm{cm}^{-3}=62.4274 \mathrm{lb} / \mathrm{ft}^{3}\right)$.

${ }^{\mathrm{t}}$ Means within column followed by the same letter are not significantly different based on Waller-Duncan $\mathrm{k}$ ratio $t$ tests at $\alpha=0.05(\mathrm{n}=3)$. in a greenhouse (described above), and were hand-watered as needed when plants began to show signs of wilt.

Substrates were analyzed for particle size distribution by passing a $100-\mathrm{g}$ air-dried sample through 12.5-, 9.5-, 6.35-, 3.35-, 2.36-, 2.0-, $1.4-, 1.0-, 0.5-, 0.25-$, and $0.11-\mathrm{mm}$ sieves with particles passing the 0.11 $\mathrm{mm}$ sieve collected in a pan. Sieves were shaken for 3 min with a Ro-Tap (Ro-Tap RX-29; W.S. Tyler, Mentor, $\mathrm{OH}$ ) sieve shaker (278 oscillations/ min, 159 taps/min). Substrate air space (AS), container capacity (CC), and total porosity (TP) were determined following procedures described by Bilderback et al. (1982). Substrate bulk density (measured in grams per cubic centimeter) was determined from $347.5 \mathrm{~cm}^{3}$ samples dried in a $105^{\circ} \mathrm{C}$ forced-air oven for $48 \mathrm{~h}$. Substrate $\mathrm{pH}$ and electrical conductivity (EC) of ageratum were determined at 1,15 , and $30 \mathrm{~d}$ after planting (DAP) using the PourThru technique (Wright, 1986). Only one species was used to measure $\mathrm{pH}$ and EC in this study. Media shrinkage (centimeters below the top of the container) was measured at 7 and 41 DAP. Leaf chlorophyll content was quantified using a SPAD-502 chlorophyll meter (Minolta Camera Co., Ramsey, NJ) at 30 DAP. Growth indices $[($ height + width + perpendicular width) $/ 3 \mathrm{~cm}$ ] were recorded at 30 DAP. A visual evaluation of the root ball (scale of $0 \%-100 \%$ root coverage of the root ball surface) was conducted at the conclusion of the study. Shoot dry weights (SDW) were recorded at the conclusion of the study (4l DAP) by drying in a forced-air oven at $70{ }^{\circ} \mathrm{C}$ for $48 \mathrm{~h}$. Recently matured leaves (Mills and Jones, 1996) were sampled from four replications of ageratum and salvia at both locations. Samples from impatiens were not collected due to cost restrictions. Foliar samples (four replications per treatment) were analyzed for nitrogen $(\mathrm{N})$, phosphorus $(\mathrm{P})$, potassium $(\mathrm{K})$, calcium $(\mathrm{Ca})$, magnesium $(\mathrm{Mg})$, sulfur $(\mathrm{S})$, boron $(\mathrm{B})$, iron $(\mathrm{Fe})$, manganese $(\mathrm{Mn})$, copper $(\mathrm{Cu})$, and zinc $(\mathrm{Zn})$. Foliar $\mathrm{N}$ was determined by combustion analysis using a $1500 \mathrm{~N}$ analyzer (Carlo Erba, Milan, Italy). Remaining nutrients were determined by microwave digestion with inductively coupled plasma-emission 
spectrometry (Thermo Jarrel Ash, Offenbach, Germany). Data were analyzed using Waller-Duncan k ratio $t$ tests $(P \leq 0.05)$ using SAS (version 9.1; SAS Institute, Cary, NC). Data were analyzed separately for each location.

\section{Results and discussion}

Since there are no universally accepted standards for physical properties of greenhouse substrates, several recommendations have been used to evaluate the substrates in this study. Jenkins and Jarrell (1989) suggested optimal ranges of $60 \%$ to $75 \%$ TP, $50 \%$ to $65 \%$ CC , and $10 \%$ to $20 \%$ AS. Boertje (1984) recommended minimum of $85 \%$ TP and at least $45 \%$ CC. Recommended ranges for nursery crop substrates include: $50 \%$ to $85 \% \mathrm{TP}, 10 \%$ to $30 \% \mathrm{AS}, 45 \%$ to $65 \% \mathrm{CC}$, and 0.19 to $0.70 \mathrm{~g} \cdot \mathrm{cm}^{-3}$ bulk density (Yeager et al., 2007). Air space was the greatest in both of the $100 \%$ CCR treatments, which was almost $10 \%$ more than $100 \%$ PB (Table 1). Treatments containing $20 \%$ PM had the greatest CC $(53 \%-$ $56 \%$ ), while those containing $10 \% \mathrm{PM}$ had slightly less CC (45\%-51\%) and $100 \%$ CCR or PB had the least CC $(38 \%-49 \%)$. Substrates in this study all had between $84 \%$ and $87 \% \mathrm{TP}$, indicating adequate porosity, although these values are near the top of the suggested ranges [ $10 \%$ over the range suggested by Jenkins and Jarrell (1989)]. Bulk density was acceptable $\left(0.16-0.18 \mathrm{~g} \cdot \mathrm{cm}^{-3}\right)$ for all treatments, indicating that substrates were heavy enough to support plant growth yet not so heavy as to inhibit root growth as well as increase shipping costs for final product.

Recent studies in the U.S. on the effect of growing crops in substrates composed of high percentages of wood fiber have indicated similar properties to CCR. Wright and Browder (2005) demonstrated that with proper nutrition and irrigation, ground pine logs (including bark) offer potential as a container substrate when compared with $\mathrm{PB}$. Their study reported that pine wood chips provided acceptable CC (48.6\%), AS [ $40 \%$ (high but could be reduced by inclusion of more small particles)], and water drainage if the wood chips were ground finely $(0.5 \mathrm{~mm})$.

Substrate particle size distribution data (Table 2) shows that

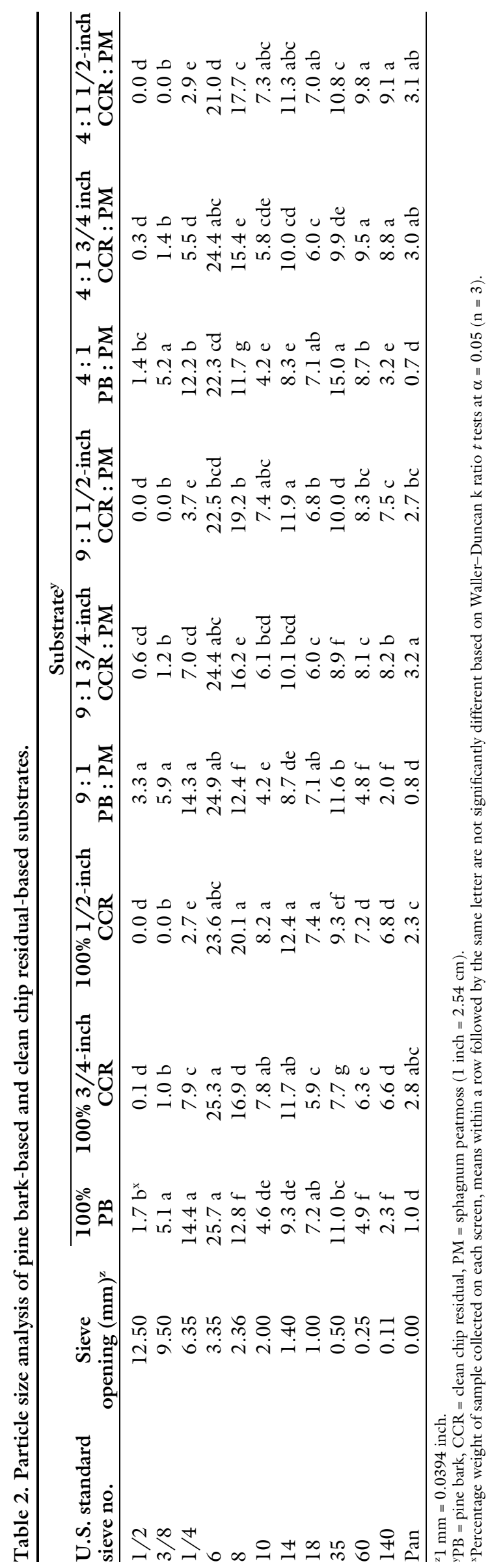


substrates containing PB had more large particles $(>6.35 \mathrm{~mm})$ than those containing CCR. The 4:1 substrate treatments had the lowest amount (65\% to $67 \%$ ) of medium-sized particles ( 1.0 to $6.35 \mathrm{~mm}$ ), while the other treatments had $70 \%$ to $76 \%$ medium-sized particles. Small particles in the substrate contribute to water-holding capacity (Bilderback et al., 2005). Too many small particles will render the substrate waterlogged and too few will result in the substrate needing frequent irrigation. The potential exists with CCR to manipulate these parameters for the needs of each crop by processing CCR at different screen sizes, mixing to enhance physical properties, and creating prescription substrates.

\section{Auburn}

Substrate EC measurements of ageratum were generally high $(2.56$ to $3.09 \mathrm{mS} \cdot \mathrm{cm}^{-1}$ ) at $1 \mathrm{DAP}$ (recommended range of 1.20 to 2.40 $\mathrm{mS} \cdot \mathrm{cm}^{-1}$; Cavins et al., 2000; Table 3). Substrate EC may have been high initially due to the substrate treatments being mixed in Poplarville $2 \mathrm{~d}$ before being planted in Auburn. The control release fertilizer may have begun to release salts in Auburn before the containers had been planted. At $15 \mathrm{DAP}$, all substrate EC levels except $100 \%$ PB (low) were within recommended range. At 30 DAP, most treatments had EC measurements within recommended ranges except for $100 \% \mathrm{~PB}$, which was low $\left(0.70 \mathrm{mS} \cdot \mathrm{cm}^{-1}\right)$ and $1 / 2$ inch CCR:PM (9:1 and 4:1), which had elevated EC levels (2.51 and 3.19 $\left.\mathrm{mS} \cdot \mathrm{cm}^{-1}\right)$. All substrate $\mathrm{pH}$ levels were generally within the recommended $\mathrm{pH}$ range (5.5-6.0; Cavins et al., 2000) for the duration of the study.

Ageratum. Leaf chlorophyll content for plants grown in 100\% PB, 9:1 PB:PM, and 4:1 CCR:PM were slightly lower than plants grown in $100 \% 3 / 4$-inch CCR (Table 4). While these differences were statistically significant, the visual difference was minimal. There were no differences among treatments for plant height, average width, GI, or SDW at 30 DAP.

Ageratum tissue nutrient analysis (Table 5 ) revealed high levels of $\mathrm{N}, \mathrm{B}$, $\mathrm{Fe}, \mathrm{Cu}$, and $\mathrm{Zn}$ among all treatments when compared with average levels of

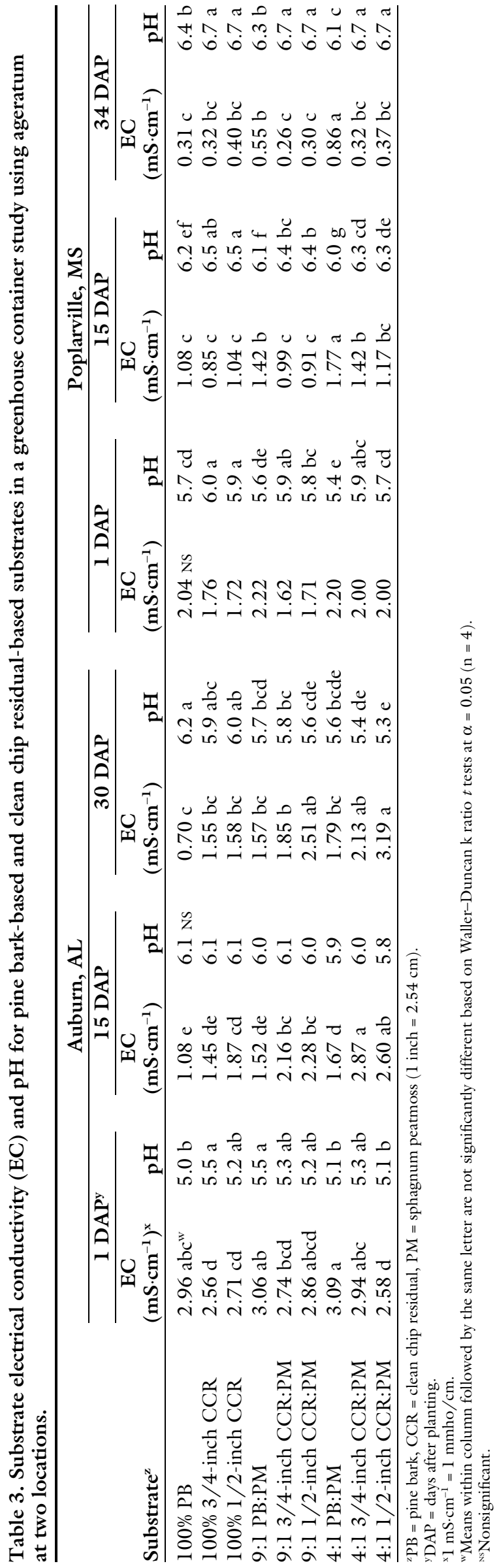




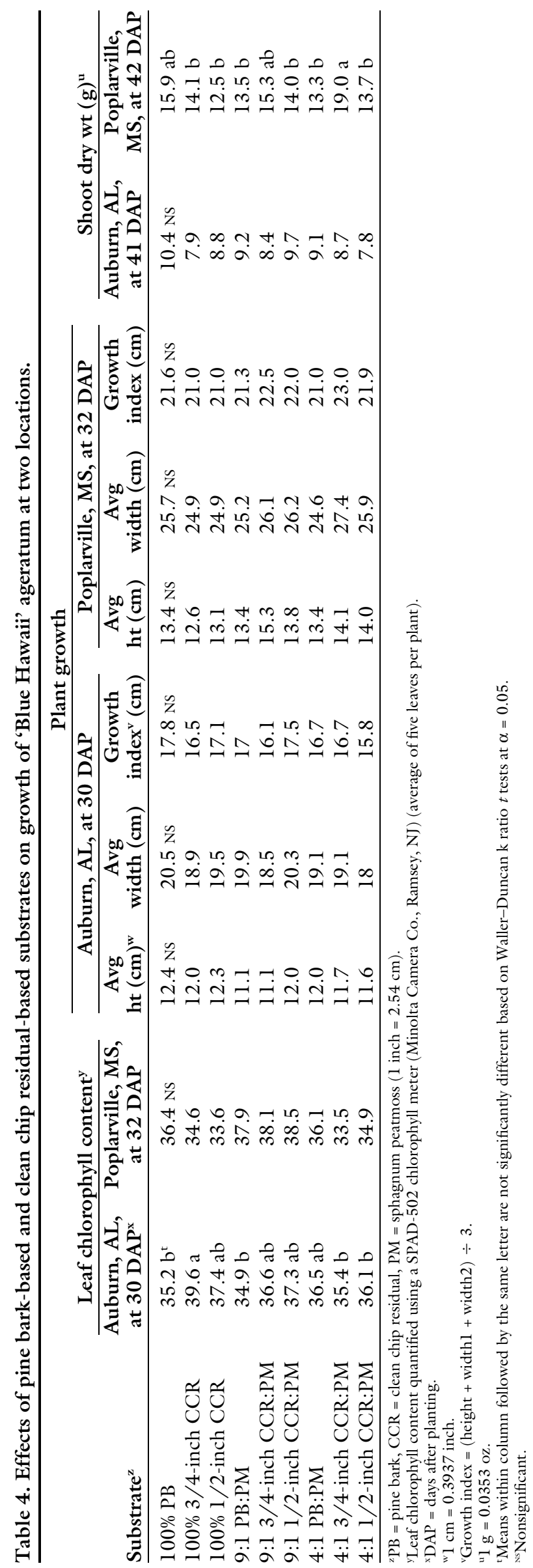

ageratum tissue nutrient content (Mills and Jones, 1996). Concentrations of $\mathrm{P}, \mathrm{K}, \mathrm{Ca}, \mathrm{Mg}$, and $\mathrm{S}$ were near the survey average. Tissue content of Mn was high in treatments containing CCR and 4:1 PB:PM. No toxicity or deficiency symptoms were observed. Fain and Gilliam (2006) reported increased foliar Mn in vinca (Catharanthus roseus) grown in WholeTree (ground up entire shoot portion of the tree) substrate.

Salvia. There were no differences in leaf chlorophyll content (Table 6). Plant height at 30 DAP was greatest in PB treatments. There was no difference among treatments for average plant width at 30 DAP. Growth indices were greatest in 9:1 and 4:1 PB:PM. The lowest GI occurred with salvia grown in CCR:PM combinations. Salvia SDW was the greatest in 4:1 PB:PM (18.7 $\mathrm{g})$. Tissue nutrient content for salvia (Table 7) was within sufficiency ranges for all elements except $S, M n$, and $\mathrm{Zn}$. Sulfur was low in all treatments. Manganese was high in treatments containing CCR. Zinc was high in all treatments. No toxicity or deficiency symptoms were observed.

IMPATIENS. Treatments containing PB had less leaf chlorophyll content than the other treatments (Table 8). Fain et al. (2006) evaluated WholeTree in production of herbaceous greenhouse crops. This study indicated mixed results with leaf chlorophyll content, which was similar for petunia, but marigold and lantana plants had a general trend of an increase in chlorophyll content with an increase in substrate PM content. Plant height was greatest in 4:1 PB:PM $(11.4 \mathrm{~cm})$. The average plant width, GI, and SDW followed a similar trend with $\mathrm{PB}$ treatments having the greatest growth.

\section{Poplarville}

Substrate EC measurements were within recommended values of 1.20 to $2.40 \mathrm{mS} \cdot \mathrm{cm}^{-1}$ (Cavins et al., 2000) at 1 DAP. At 15 DAP, EC in the substrates had fallen below the recommended range except for 9 : 1 PB:PM, 4:1 PB:PM, and 4:1 3/ 4-inch CCR:PM. At 34 DAP, all readings were low (0.26-0.86 $\left.\mathrm{mS} \cdot \mathrm{cm}^{-1}\right)$.

Substrate leachate $\mathrm{pH}$ levels at Poplarville were acceptable 1 DAP (recommended range 5.5-6.0; 
Table 5. Tissue nutrient content of 'Blue Hawaii' ageratum grown in pine bark-based and clean chip residual-based substrates at two locations.

\begin{tabular}{|c|c|c|c|c|c|c|c|c|c|c|c|}
\hline \multirow[b]{2}{*}{ Substrate $^{\mathrm{z}}$} & \multicolumn{11}{|c|}{ Tissue nutrient content $\mathrm{t}^{\mathrm{y}}$} \\
\hline & $\mathbf{N}(\%)$ & $\mathbf{P}(\%)$ & $\mathrm{K}(\%)$ & $\mathrm{Ca}(\%)$ & $\operatorname{Mg}(\%)$ & S (\%) & $\mathrm{B}(\mathrm{ppm})$ & $\mathrm{Fe}(\mathrm{ppm})$ & Mn (ppm) & $\mathrm{Cu}(\mathrm{ppm})$ & $\mathrm{Zn}(\mathrm{ppm})$ \\
\hline \multicolumn{12}{|c|}{ Auburn, AL } \\
\hline $100 \% \mathrm{~PB}$ & $3.5 \mathrm{~d}^{\mathrm{x}}$ & $0.36 \mathrm{NS}$ & $3.4 \mathrm{a}$ & $2.7 \mathrm{NS}$ & $1.9 \mathrm{~d}$ & $0.71 \mathrm{NS}$ & $53 \mathrm{NS}$ & $1465 \mathrm{~d}$ & $393 \mathrm{~d}$ & $23 \mathrm{~cd}$ & $228 \mathrm{NS}$ \\
\hline $100 \% 3 / 4$-inch CCR & $4.2 \mathrm{a}$ & 0.36 & $2.0 \mathrm{~cd}$ & 3.3 & $2.2 \mathrm{bc}$ & 0.92 & 52 & $861 \mathrm{e}$ & $1094 \mathrm{~b}$ & $36 \mathrm{a}$ & 243 \\
\hline $100 \% 1 / 2$-inch CCR & $4.1 \mathrm{ab}$ & 0.29 & $2.5 \mathrm{bcd}$ & 3.1 & $2.1 \mathrm{~cd}$ & 0.79 & 51 & $1100 \mathrm{e}$ & $814 \mathrm{c}$ & $29 \mathrm{bc}$ & 228 \\
\hline 9:1 PB:PM & $3.7 \mathrm{bcd}$ & 0.37 & $3.0 \mathrm{ab}$ & 3.1 & $2.2 \mathrm{bc}$ & 0.59 & 65 & $2062 \mathrm{bc}$ & $476 \mathrm{~d}$ & $19 \mathrm{~d}$ & 250 \\
\hline 9:1 3/4-inch CCR:PM & $4.0 \mathrm{abc}$ & 0.34 & $1.8 \mathrm{~d}$ & 3.4 & $2.4 \mathrm{ab}$ & 0.84 & 59 & $1731 \mathrm{~cd}$ & $1170 \mathrm{~b}$ & $28 \mathrm{bc}$ & 256 \\
\hline 9:1 1/2-inch CCR:PM & $4.0 \mathrm{abc}$ & 0.32 & $2.7 \mathrm{abc}$ & 3.2 & $2.2 \mathrm{bc}$ & 0.78 & 63 & $1864 \mathrm{c}$ & $1100 \mathrm{~b}$ & $30 \mathrm{ab}$ & 270 \\
\hline 4:1 PB:PM & $3.5 \mathrm{~cd}$ & 0.41 & $2.8 \mathrm{abc}$ & 3.1 & $2.3 \mathrm{bc}$ & 0.64 & 69 & $2426 a$ & $725 c$ & $23 \mathrm{~cd}$ & 274 \\
\hline 4:1 3/4-inch CCR:PM & $3.6 \mathrm{bcd}$ & 0.33 & $2.3 \mathrm{bcd}$ & 3.3 & $2.4 \mathrm{ab}$ & 0.68 & 72 & $2560 \mathrm{a}$ & 1346 a & $23 \mathrm{~cd}$ & 257 \\
\hline 4:1 1/2-inch CCR:PM & $3.6 \mathrm{~cd}$ & 0.31 & $2.1 \mathrm{~cd}$ & 3.4 & $2.6 \mathrm{a}$ & 0.78 & 64 & $2364 \mathrm{ab}$ & $1226 \mathrm{ab}$ & $30 \mathrm{ab}$ & 251 \\
\hline \multicolumn{12}{|c|}{ Poplarville, MS } \\
\hline $100 \% \mathrm{~PB}$ & $5.4 \mathrm{NS}$ & $0.41 \mathrm{ab}$ & $2.8 \mathrm{c}$ & $2.2 \mathrm{NS}$ & $1.2 \mathrm{a}$ & $0.52 \mathrm{NS}$ & $95 \mathrm{NS}$ & $862 \mathrm{NS}$ & $877 \mathrm{a}$ & $17 \mathrm{Ns}$ & 154 NS \\
\hline $100 \% 3 / 4$-inch CCR & 5.3 & $0.26 \mathrm{~d}$ & $2.8 \mathrm{c}$ & 1.6 & $0.9 \mathrm{~b}$ & 0.47 & 83 & 291 & $365 \mathrm{~b}$ & 20 & 131 \\
\hline $100 \% 1 / 2$-inch CCR & 5.8 & $0.37 \mathrm{bc}$ & $3.1 \mathrm{bc}$ & 2.2 & $1.2 \mathrm{a}$ & 0.61 & 94 & 263 & $354 \mathrm{~b}$ & 18 & 127 \\
\hline 9:1 PB:PM & 5.5 & $0.42 \mathrm{ab}$ & $3.1 \mathrm{bc}$ & 2.3 & $1.3 \mathrm{a}$ & 0.57 & 93 & 640 & $440 \mathrm{~b}$ & 15 & 167 \\
\hline 9:1 3/4-inch CCR:PM & 5.1 & $0.32 \mathrm{~cd}$ & $3.9 \mathrm{a}$ & 2.0 & $1.1 \mathrm{a}$ & 0.53 & 90 & 532 & $382 \mathrm{~b}$ & 16 & 149 \\
\hline 9:1 1/2-inch CCR:PM & 5.2 & $0.37 \mathrm{bc}$ & $3.6 \mathrm{ab}$ & 1.9 & $1.1 \mathrm{a}$ & 0.53 & 92 & 357 & $391 \mathrm{~b}$ & 17 & 156 \\
\hline 4:1 PB:PM & 5.9 & $0.45 \mathrm{a}$ & $3.2 \mathrm{abc}$ & 2.5 & $1.3 \mathrm{a}$ & 0.54 & 91 & 676 & $493 \mathrm{~b}$ & 15 & 144 \\
\hline 4:1 3/4-inch CCR:PM & 5.1 & $0.27 \mathrm{~d}$ & $3.4 \mathrm{abc}$ & 2.3 & $1.2 \mathrm{a}$ & 0.74 & 88 & 405 & $371 \mathrm{~b}$ & 16 & 129 \\
\hline 4:1 1/2-inch CCR:PM & 5.5 & $0.36 \mathrm{bc}$ & $3.4 \mathrm{abc}$ & 2.1 & $1.1 \mathrm{a}$ & 0.58 & 90 & 282 & $281 \mathrm{~b}$ & 14 & 112 \\
\hline$\underline{S u r v e y ~ a v g ~}^{\mathrm{w}}$ & 2.82 & 0.42 & 2.10 & 3.61 & 2.19 & 0.73 & 33 & 428 & 474 & 6 & 107 \\
\hline
\end{tabular}

${ }^{2} \mathrm{~PB}=$ pine bark, $\mathrm{CCR}=$ clean chip residual, $\mathrm{PM}=$ sphagnum peatmoss $(\mathrm{l}$ inch $=2.54 \mathrm{~cm})$

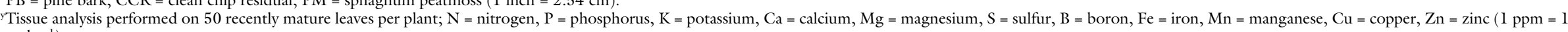
$\left.\mathrm{mg} \cdot \mathrm{kg}^{-1}\right)$.

Means within column and location followed by the same letter are not significantly different based on Waller-Duncan $\mathrm{k}$ ratio $t$ tests at $\alpha=0.05(\mathrm{n}=4)$.

"Survey average published by Mills and Jones (1996).

Nonsignificant. 


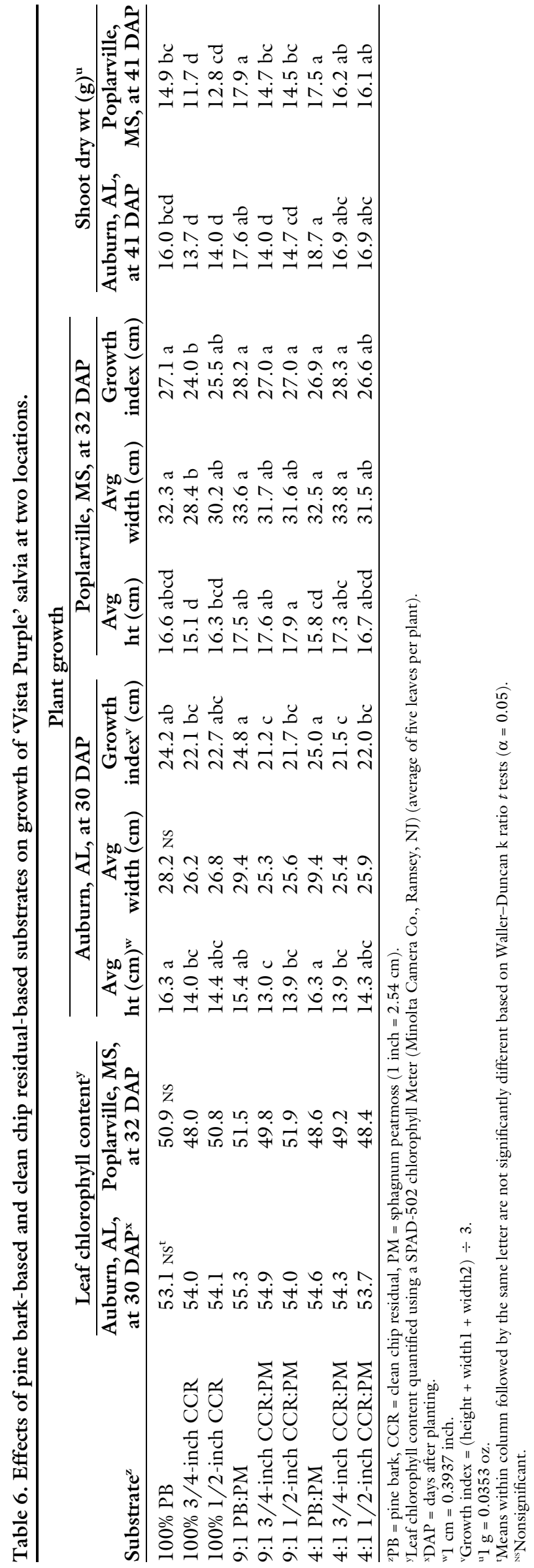

Cavins et al., 2000), but began to rise slightly at 15 and 34 DAP (6.1 to 6.7). At 15 and $34 \mathrm{DAP}$, treatments containing $\mathrm{PB}$ had lower $\mathrm{pH}$ levels (range 6.1-6.3) than other treatments (average 6.4-6.7).

Ageratum. No differences were measured in leaf chlorophyll content at 32 DAP (Table 4). Plant height, average width, and GI were similar for all treatments at $32 \mathrm{DAP}$. Ageratum grown in 4:1 3/4-inch CCR:PM had greater SDW $(19.0 \mathrm{~g})$ than all the other treatments except $100 \%$ PB and 9:1 3/4-inch CCR:PM. Similar results were reported by Fain et al. (2006) with annual vinca grown in WholeTree having similar growth to plants grown in $\mathrm{PB}$. While SDW were $15 \%$ greater for plants grown in $100 \%$ $\mathrm{PB}$ than those grown in WholeTree $60 \mathrm{DAP}$, there were no differences in plant GI.

Ageratum tissue nutrient analysis (Table 5) revealed high levels of $\mathrm{N}, \mathrm{B}, \mathrm{Cu}$, and $\mathrm{Zn}$ among all treatments (Mills and Jones, 1996). Concentrations of $\mathrm{P}$ and $\mathrm{K}$ were close to the survey average, while $\mathrm{Ca}, \mathrm{Mg}$, and $S$ were slightly low. Treatments containing CCR had the lowest concentrations of Fe. Manganese concentration was almost double in $100 \% \mathrm{~PB}$ when compared with other treatments which were near the survey average published by Mills and Jones (1996). No toxicities or deficiencies were observed for the duration of the study.

Salvia. There were no differences in leaf chlorophyll content (Table 6). Plants grown in 9:1 $1 / 2$-inch CCR:PM had the greatest plant height $(17.9 \mathrm{~cm})$. The average plant width was similar in all treatments except $100 \% 3 / 4$-inch CCR, which was slightly smaller. Growth indices showed the least growth in $100 \%$ 3/4-inch CCR. Results for SDW showed that the greatest SDW occurred in combinations of PB:PM. Both of the 100\% CCR treatments had the least growth. Tissue nutrient content for salvia (Table 7 ) was within sufficiency ranges for all elements except $S$, which was low. Treatments containing CCR:PM blends had low amounts of K. Manganese was high in 100\% PB and 9:1 PB:PM. Zinc was only slightly above the sufficiency range for a few treatments. No toxicity or deficiency symptoms were observed. 


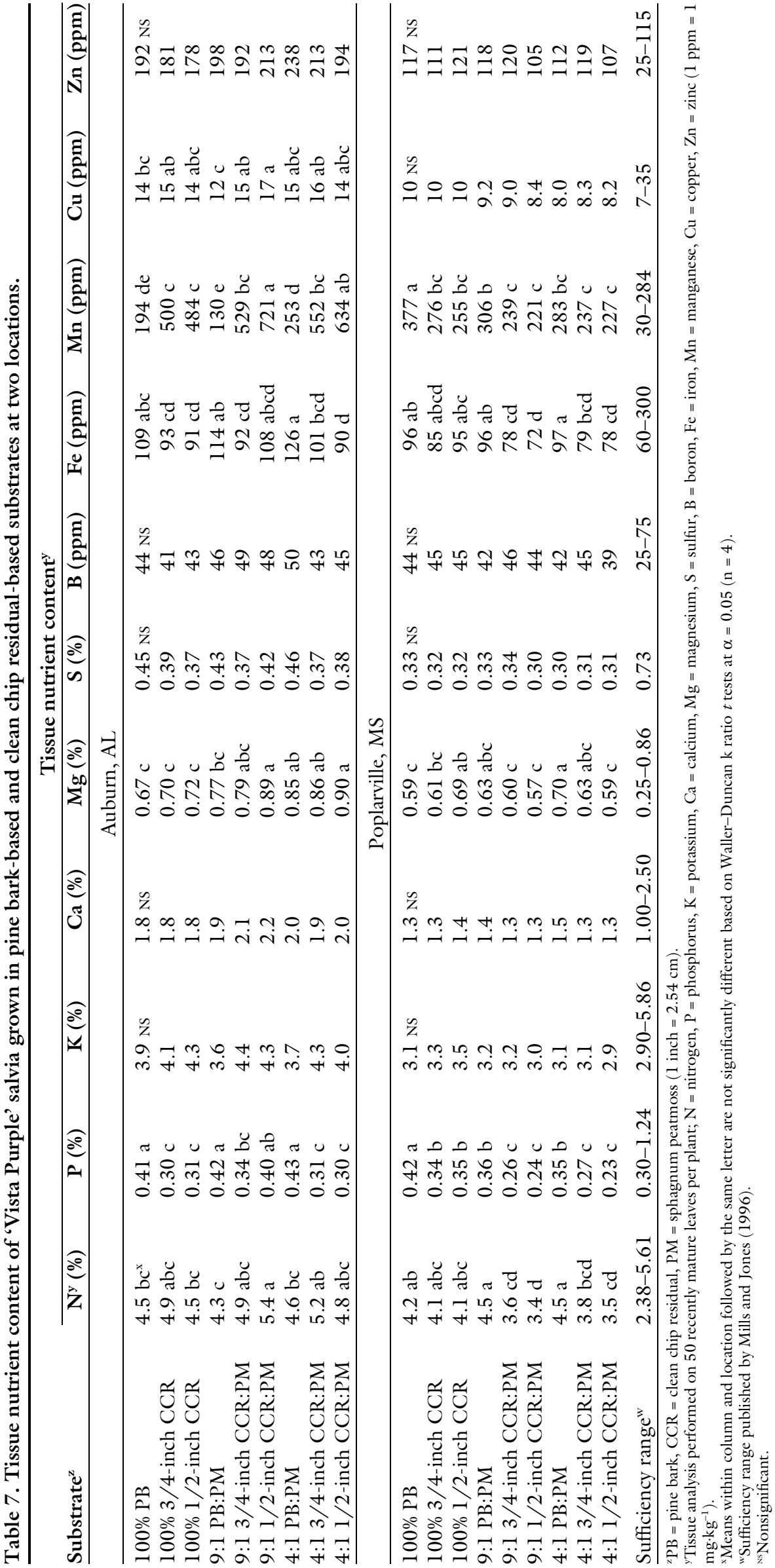

IMPATIENS. No differences among treatments for leaf chlorophyll content were recorded (Table 8). Plant height was greatest for 4:1 PB:PM. There were no differences among impatiens plants for average plant width or GI. The treatment producing the highest SDW was 4:1 PB:PM.

Substrate shrinkage occurs when the substrate decomposes due to microbial activity in the root zone, which compacts the remaining material (Kenna and Whitcomb, 1985; Robbins, 2002). Containers having reduced capacity for root growth are not as marketable as full containers. In this study, no differences among treatments were observed for substrate shrinkage at either location (data not shown). For each species, root ratings were similar among all treatments (data not shown). Root growth of all plants was uniform over the entire root ball. There were no odors or diseases observed with any of the substrate blends in this study. Wright and Browder (2005) reported that substrate analysis of pine wood chips indicated there were no toxic nutrient levels associated with the material and the $\mathrm{pH}$ (5.7) was acceptable for plant culture. Also in this study by Wright and Browder (2005), no apparent shrinkage due to decomposition over the course of the test was reported. Root growth was more extensive in ground pine wood chips than in agedmilled PB (Wright and Browder, 2005).

Results of this study concur with results obtained by Wright and Browder (2005) and Fain et al. (2006) where annuals grown in wood-based substrates can have comparable growth to plants grown in traditional $\mathrm{PB}$ substrates. Ageratum and salvia plants had fewer differences among treatments than impatiens, which indicated that further studies with more species will need to be evaluated for growth in wood-based substrates. Differences among impatiens were attributed to using different impatiens cultivars. Treatments composed of $100 \%$ CCR generally had too much AS, which lowered water-holding capacity (Table 1), possibly explaining some of the reduced growth measurements (Tables 4, 6, and 8). A smaller screen-sized material may be more suitable for greenhouse 


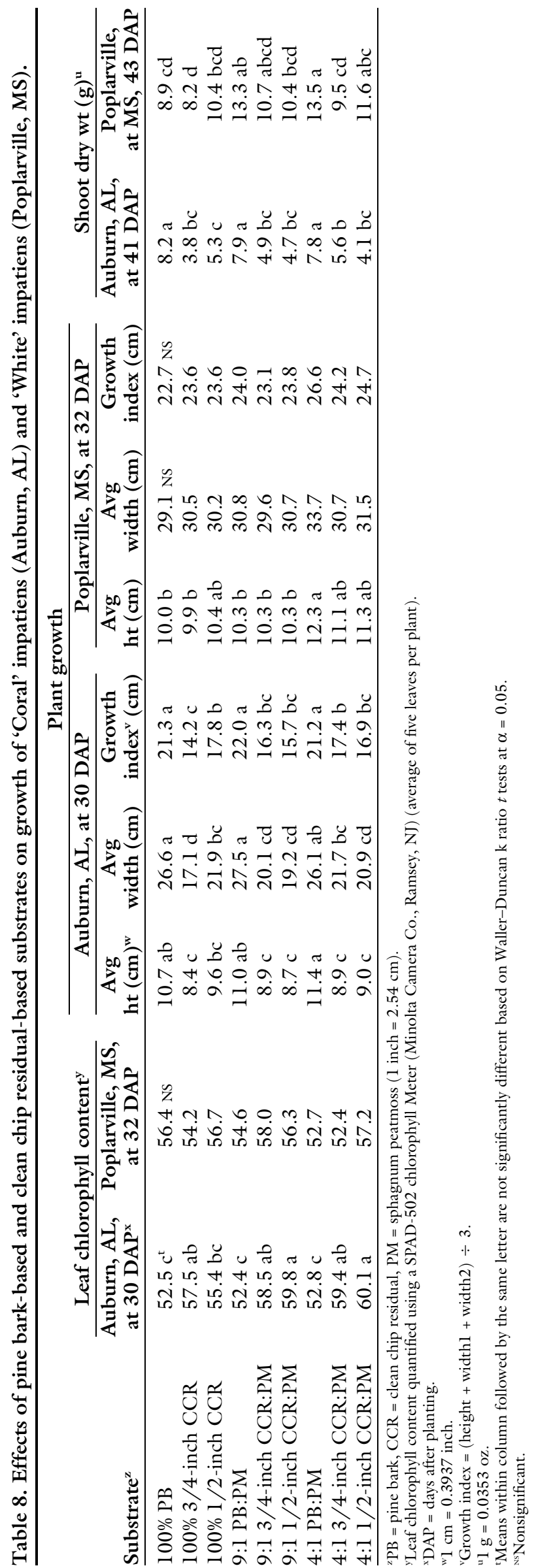

production of annual plants if CCR is used alone. Blending CCR and $\mathrm{PB}$ with $\mathrm{PM}$ increased water-holding capacity as the percentage of PM increased (Table 1). In general, when PM was a component, plant growth was similar regardless of $\mathrm{PB}$ or CCR rate. These results confirm that freshly processed CCR is a promising alternative substrate component or $\mathrm{PB}$ replacement for producing greenhouse-grown annuals in large containers.

\section{Literature cited}

Bilderback, T.E., W.C. Fonteno, and D.R. Johnson. 1982. Physical properties of media composed of peanut hulls, pine bark and peat moss and their effects on azalea growth. J. Amer. Soc. Hort. Sci. 107:522-525.

Bilderback, T.E., S.L. Warren, J.S. Owen, Jr., and J.P. Albano. 2005. Healthy substrates need physicals too! HortTechnology 15:747-751.

Boertje, G.A. 1984. Physical laboratory analysis of potting composts. Acta Hort. 150:47-50.

Cavins, T.J., B.E. Whipker, W.C. Fonteno, B. Harden, I. McCall, and J.L. Gibson. 2000. Monitoring and managing $\mathrm{pH}$ and EC using the PourThru extraction method. North Carolina State Univ. Coop. Ext. Hort. Info. Lflt. 590.

Fain, G.B. and C.H. Gilliam. 2006. Physical properties of media composed of ground whole pine trees and their effects on vinca (Catharanthus roseus) growth. HortScience 40: 510. (Abstr.).

Fain, G.B., C.H. Gilliam, J.L. Sibley, and C.R. Boyer. 2006. Evaluation of an alternative, sustainable substrate for use in greenhouse crops. Proc. Southern Nursery Assn. Res. Conf. 51: 651-654.

Jenkins, J.R. and W.M. Jarrell. 1989. Predicting physical and chemical properties of container mixtures. HortScience 24:292-295.

Kenna, S.W. and C.E. Whitcomb. 1985. Hardwood chips as an alternative medium for container plant production. HortScience 20:867-869.

Lu, W., J.L. Sibley, C.H. Gilliam, J.S. Bannon, and Y. Zhang. 2006. Estimation of U.S. bark generation and implications for horticultural industries. J. Environ. Hort. 24:29-34. 


\section{Research Reports}

Mills, H.A. and J.B. Jones. 1996. Plant analysis handbook II. MicroMacro Publishing, Athens, GA.

Robbins, J.A. 2002. Effect of media type on the growth of containergrown woody ornamentals. Proc. Southern Nursery Assn. Res. Conf. 47:6772 .
Wright, R.D. 1986. The pour-thru nutrient extraction procedure. HortScience 21:227-229.

Wright, R.D. and J.F. Browder. 2005. Chipped pine logs: A potential substrate for greenhouse and nursery crops. HortScience 40:1513-1515.
Yeager, T., T. Bilderback, D. Fare, C. Gilliam, J. Lea-Cox, A. Niemiera, J. Ruter, K. Tilt, S. Warren, T. Whitwell, and R. Wright. 2007. Best management practices: Guide for producing nursery crops. 2nd ed. Southern Nursery Assn., Atlanta. 